\title{
EDITORIAL
}

\section{Feminist Critical Theory in English Canada and Quebec: Present State and Future Directions}

Cassandra's art has always been a perilous one. Framed in the future tense, her words were intended to prevent disaster. To speak out against the powerful family narrative led to her exclusion and isolation, her pronouncements received as nonsense. As an incitement to future action, they produced no transformation. Though Cassandra's prophecy was ineffective, her example has not deterred contemporary feminists from writing in the future perfect. Indeed, the Utopian mode has been a dominant trait of contemporary feminist discourse as it seeks to change the world by changing the way we look at and construct reality. Emphasizing the transformed lives of their characters, and describing alternate societies which would make new patterns of behaviour and interpersonal relations possible, the utopian feminist novels of the 1970's provide the reader with an experience, albeit limited, of what a better world beyond sexual heirarchy and domination might be like. But the optimism of Utopias structured by feminist principles and ideals is giving way to the pessimistic or cautionary tales of dystopias published in the 1980's. What is the impact of the changes in narrative in terms of discursive strategies aimed at subverting the dominant discourse and building a new society?

As a critique of the social blueprints of the new right, with their glorification of REAL women and their attempts to curtail the gains made by feminists in the sixties and seventies to control their bodies and lives, are these dystopias only a retreat from earlier optimism when the dream of a post-patriarchal society seemed soon to be realized? A reader of these narratives makes this suggestion: "In the closing years of Reagan's second term there are increasing attempts to roll back the gains of the 70's." May the revival of these cautionary tales not also indicate a shift in the dominant mode of North American feminist discourse away from the prescriptive role of liberal and radical feminist theory - gynocritics - with its emphasis on positive images for women in a new society toward the critique emanating from socialist and French feminist theory? Such feminist deconstruction emphasizing the significance of literature and other cultural media as technolo- 
gies of gender and establishing "woman" as a position within discourse, not as a biological essence, instructs us to reread, to offer as provisional our theoretical fictions, and to subject them to the dialogical process of listening to the other. This tactic would lead feminists to foreground a critique of feminism itself. It would encourage a focus on the differences within feminism, on the gaps and silences of the feminist project.

Advances were made in the sixties and seventies in terms of women's greater political equality and participation in the public sphere. As well, transformations were initiated by theorizing women's sexual and domestic lives in recognition that the personal is political. This new focus on difference incited feminists to extend their theorization to interweave the question of gender with an analysis of class and race. This focus on difference appears to be the major question of the 1980's, unless feminism itself has become obsolete. Is the darkening of Cassandra's vision, the second failure to act on her prophecies, a retreat or renewal? This is an important question to raise at a time when the term post-feminism is being used by the media to characterize the women's movement in the 1980's. When, though, have you ever heard them speak of post-patriarchy?

"Meet the Post-feminist Woman," Bronwyn Drainie invites the readers of Chatelaine, once upon a time a bastion of feminist thought. "In the ' $60 \mathrm{~s}$, women rebelled against constraints of domesticity and fought the good fight for political equality and financial independence," she writes, but the rhetoric of the struggle is "embarrassing" to younger women. ${ }^{2}$ While admitting that most real barriers to women's equality are still in place, Drainie yet hails the new focus on individualism that has replaced feminism's aim of total social transformation. Feminism, Yuppie style, is how this article might better be titled to underline its focus on dressing for success, finding the right nannie or the right scheduling of one's work in a week in order to allow women to have it all; six-figure salary, children and large house. In claiming novelty for women's mothering activities, Drainie exhibits her ignorance of contemporary feminist theory where motherdaughter relations with the non-hierarchical mode of reciprocal relating have been at the centre of a proposed new social order. The implication of Drainie's argument has been criticized by Susan Crean for its "crass commercialism." But underlying the sartorial metaphor which "makes feminism safe for the fashion industry . . . the arrival of feminism in the mainsteam" (p. 39) is an unquestioned ideological shift, a paradox emerging from the pursuit of a liberal feminist 
programme of social equality which becomes ipso facto a conservative position that denies the systematic oppression of women.

The Baby Boomers' exercize of the new choice to pursue a career as a result of feminist struggles in the sixties for birth control, day care and equal representation in the work force is a manifestation of a rugged individualism which leads them to take the blame for their inequality as women on their own shoulders, celebrating the power of the victim. This "refusal to blame others" is anti-feminist, for the basic tenet of feminism is the recognition of women's oppression by the social order, though feminists disagree on the grounds of the oppression and on the means for eliminating it.

What Crean barely hints at in her critique of the superficial and incorrect image of feminism being presented through the media and what Drainie's article ignores is feminism's epistemological project with its claim not just to obtain equality for women in the job market, but to transform the ways in which we perceive the world and the methods by which we arrive at this new knowledge. Some feminists would extend this epistemological revolution from the challenge to academic disciplines and symbolic order into the emergence of a cognitive revolution - women think differently from men - which would lead to a restructuring of the conceptualization of social and intellectual relations. These are the claims being advanced in the academy by feminist scholars who consider that a conceptual revolution is the necessary premise for a social revolution.

Feminism's intellectual inquiry has theorized the concept of gender as sexual difference as central to representation, textuality, reading and writing in the physical and human sciences. Gender is understood to be a classifactory term for morphology and sex, so that sex $=$ gender is a symbolic system which assigns meaning to individuals. Feminists note the assymetry of all gender systems which are both the product and process of the representations. They also note the workings of the ideology of gender, gender being an effect of representaion. Gender is not a sphere separate from ideology but a primary instance of ideology, a set of social relations within which men and women are positioned differently in discursive formations. Ideology represents not the real but the imaginary in relationship to the real. The feminist project attempts to rewrite both the product and process of representation and self-representation. It explores the irreconcilable contradiction of being both inside and outside representation, of being constructed as woman within the dominant discourse, and yet experiencing the heterogeneity of historical subjects, of being women outside that 
discourse. The awareness of this conflict leads to our consciousness of complicity in the gender system. This, in turn, has led to a change in the focus of feminist inquiry since the 60's when the focus on sexual difference concentrated attention on the elaboration of hypotheses regarding gendered spaces. The difference in question was the difference between men and women, and feminists attempted to chart female specificity and the contours of an emerging female culture, whether this was the positing of counter-representations of the dominant culture or locating oneself in "the wild zone, "' on the margins of that culture, both areas constituting all female Utopias. But this discourse on sexual difference was still caught up within binary logic and was, moreover, always already inscribed in the master political narratives which reproduced themselves even in feminine narratives.

The feminist critique of the natural sciences led the way in evolving a feminist epistemology which made clear the complicity of feminists within the gender system. The challenges of women of colour with their own resistance to dominant ways of seeing and the commodification of culture, "blowing wide open the myths and hidden assumptions - the knowledge that continues to foster the practice of forgetting,"' renewed feminists' consciousness of complicity in oppression. From this consciousness has emerged a new problematic, that of exploring what the Quebec feminists have long termed "femmes plurielles," of writing women into history with all their multiple contexts of nationality, language, class and race. No longer constrained in terms of human universals by the concepts of the two sexes, feminist inquiry sets out to look at the differences among women, the differences within feminism. It also attempts to distinguish women from woman, to explore the trajectories of women in their historical context as they are distinct from woman as sign within discourse.

Feminist inquiry in the 80's analyzes the signifying practices which position women as woman within a variety of discourses, especially philosophical in which the subject is constituted, and political in which the subject is bound into sets of power relations operating throughout social existence. It also investigates the discursive mechanisms through which the subject is caught up and bound into the ideology of gender, into the subject position of woman, subjectivity here being understood as an effect of language and not a biological entity. In analyzing the apparati of knowledge and power, feminist inquiry concentrates on analyzing the semiotic apparatus through which meaning is assigned to the individual in the symbolic order, a sociocultural construct. Literature, a technology of gender ${ }^{6}$ like other cultural signifying practices, offers a privileged terrain for the binding 
of the individual subject into representation and so is an important area of investigation for feminist inquiry.

Here then is my offering - my metatheoretical flight in defence of discourse studies and questions of textuality as the future direction for feminist literary theory. For, unlike Drainie and Crean, I'm not singing the post-feminist blues these days.

Barbara Godard

\section{Notes}

'Peter Fitting, "The Decline of the Feminist Utopian Novel," Borderlines, 7/8 (Spring/Summer 1987), p. 19.

'Bronwyn Drainie, "Meet the Postfeminist Woman," Chatelaine, September 1986, pp. 59 and 95.

${ }^{3}$ Susan Crean, "Post-modernism and Power Dressing: Who Says the Women's Movement Has Run Out of Steam?" This Magazine, 20 No. 4 (October/November 1986), p. 38.

${ }^{4}$ Elaine Showalter, "Feminist Criticism in the Wilderness," Critical Inquiry, 8, No. 2 (Winter 1981), p. 200.

'Marlene Nourbese Philip, "Social Barbarism and the Spoils of Modernism: Notes from the Margin," Fuse, Spring 1987, p. 32.

"Teresa de Laurentis, "The Technology of Gender," Seminars at ISISSS, Toronto, June 1987. 